\title{
THE EFFECTS OF MEDIA DISPLAYS REGARDING TERRORIST AT- TACKS ON ATTITUDES CONCERNING TOURIST DESTINATION PLANNING
}

\section{UČINCI MEDIJSKIH PREZENTACIJA TERORISTIČKIH NAPADA NA STAVOVE PLANIRANJA TURISTIČKE DESTINACIJE}

\author{
Barbara Pavlakovičำ, Mladen Knežević1 ${ }^{1}$, Marko Koščak ${ }^{1}$, Tony O'Rourke², Boris \\ Prevolšek ${ }^{1}$, Boštjan Brumen ${ }^{1}$ \\ Faculty of Tourism, University of Maribor, Brežice, Slovenia ${ }^{1}$; Research Advisor at Co-operatives, United Kingdom ${ }^{2}$ \\ Fakultet za turizam, Sveučilište u Mariboru, Brežice, Slovenija ${ }^{1}$; Co-operatives, Ujedinjeno kraljevstvo ${ }^{2}$
}

Abstract

Designing and presenting a destination as a tourist product is a process, which is influenced by different issues. Among them are perceptions of destination and attitudes towards a destination. In this study we have examined how media representation of destination safety and security affects attitudes about tourism destinations. Safety and security are important questions in the field of tourism and therefore we initially present differing aspects of this topic. This research question was addressed as an experiment among students of tourism, who are future tourism product designers. The independent variable was the projection of terrorist attack films on observed destinations. The experiment used different questionnaires - among them was a nonverbal semantic differential. The results of these questionnaires showed that the perception of different destinations is lower than before the experiment and therefore that the safety and security issues are important factors when designing a tourist product.
Sažetak

Projektiranje i predstavljanje destinacije kao turističkog proizvoda je proces na koji utječu različiti problemi. Među njima su i percepcije destinacije i stavovi prema destinaciji. $U$ ovom smo istraživanju ispitali kako medijska prezentacija sigurnosti destinacije utječe na stavove o turističkim odredištima. Pitanja sigurnosti su važna na području turizma i zato u početku predstavljamo različite aspekte ove teme. Istraživanje je postavljeno kao eksperiment među studentima turizma koji su budući kreatori turističkih proizvoda. Nezavisna varijabla bila je projekcija filmova terorističkih napada na promatranim destinacijama. Eksperiment je koristio različite upitnike među njima je bio neverbalni semantički diferencijal. Rezultati tih upitnika pokazali su, da je percepcija različitih destinacija niža nego prije eksperimenta i stoga su sigurnosna pitanja itekako važni čimbenici pri projektiranju turističkog proizvoda. 
INTRODUCTION

The tourism industry is highly vulnerable to natural disasters - such as earthquakes, hurricanes, floods. On the other hand, the tourism industry is even more vulnerable to humancreated disasters such as terrorism, crime and war. Despite the development and continuous improvements in everyday life, security remains and important element of every society. The global impacts and dimensions of the tourism industry are responsible for strengthening the importance of the security issues from a personal to both a local and a global level. Security threats frequently occur at many popular travel destinations, therefore changing travel flows quite dramatically. Since the events on 9/11, safety procedures and security issues became an indispensable element of almost every form of travel and have significantly shaped global travel flows. The fact remains that all forms of security incidents have negatively affected the image of destinations. Security threats in most cases create changes in tourists' behaviour and their perception of risk, which usually results in the cancellation of booked trips and avoidance of the affected destinations. Tourists who are already at such a destination will seek to move to a safer place hence evacuating the destination $/ \mathbf{1} /$. According to the research of Kozak et al. /2/ the majority of travelers are more likely to change their travel plans to a destination that has elevated risk while the minority reports they are more unlikely.

According to Kurež and Prevolšek /3/, the security concept is a living form, which changes, grows and adapts to different environments, hence it represents the interesting evolution of the security concept. It is an irony that the evolution of the security concept will continue even beyond the point, when the final collapse of the humankind is to happen, despite the fact that the concept itself is about the processes, mechanisms and systems dealing with the prevention of the collapse.

\section{DESTINATION ATTRACTIONS}

Every destination offers a variety of products and services to attract visitors and each tourist has an opportunity to choose from a set of destinations. Different factors may have an influence on destination choice, i.e. age, income, personality, cost, distance, risk and motivation. Of these, tourism literature emphasises the importance of both push and pull factors in shaping tourist motivations and in choosing vacation destinations. 'Push' factors are originrelated and refer to the intangible, intrinsic desires of the individual traveller, e.g. the desire for escape, rest and relaxation, adventure, health or prestige. 'Pull' factors are mainly related to the attractiveness of a given destination and tangible characteristics such as beaches, accommodation and recreation facilities and cultural and historical resources /4/.

Travellers hold images of tourism destinations, the destination image is a crucial component for a tourists' choice of a vacation destination. It is the best basis for a management model owing to its relative simplicity, dynamism, versatility and capacity to integrate factors such as the tourist's experience and location quality /5/. It has a strong influence on tourist perceptions. The destination image has also a large role in customer satisfaction. There are two major ways of recreating a destination image in the minds of visitors after an event has occurred. The first one is through communication in the mass media, while the second one is through a real experience $/ 6 /$.

Preferences have been regarded as one of the most critical elements to explain tourist destination selection and holiday choice. Tourists have to choose which of the destinations they wish to visit and which to skip. The result is the creation of typical consumption patterns of the tourism product based on preferences.

One of the most recent classifications of tourism attractions which is also widely accepted by the scholars, is the classification developed by Ritchie and Crouch $/ 7 /$, where all tourism attractions are divided into seven main categories:

1. Physiography and climate; 

2. Culture and history;
3. Mix of activities;
4. Special events;
5. Entertainment;
6. Superstructure;
7. Market ties.

The main problem concerning the definition of tourism attractions is that there are number of factors that may significantly affect visits to a particular area but cannot be defined as tourism attractions. Those factors are economic (foreign exchange rates and costs of living); political (war and terrorism risks), sociodemographic (friendliness of local people, courtesy of public service employees) factors and risks of natural disasters (droughts, tsunamis, earthquakes etc.). This view is supported by the studies reviewed by Kim and Morrsion /8/ who concluded that factors such as actual travel experience in a tourism destination, changes in the political or social environments or socio-demographic factors, which cannot be considered as tourism attractions, may significantly affect visitation of an area.

\section{DESTINATION ATTRACTION IN THE LIGHT OF SAFETY \& SECURITY}

Safety and security are one of the key components of travel planning for every tourist. Safety is considered as a situation where risk and danger are minimised for the individual. Security is considered as an active protection from threats to provide risk free situations. The vital importance of both comes from our predisposition for fulfilling needs that Maslow described through the hierarchy of needs. The safety needs are positioned at second level just after primary biological needs. These two steps are essential for physical survival of an individual since we need to have basic nutrition, shelter and safety.

For tourists, safety and security are even more important, since tourists enter new and unknown situations on their journey. At home, risk can be more easily reduced and safety conditions more simply reachable. However, on a voyage to a foreign country, the circumstances are unpredictable and effected by many external factors. The safety and security elements that are especially interesting for tourists are firstly travel safety. This refers to air, road, rail and naval transport. Secondly, great importance lays on health safety. This category includes the control over contagious diseases and epidemics, advice about vaccinations or other preventive measures, standards for food and accommodation safety etc. The emphasis must also be put on safety and security standards at tourism sites (for example skiing slopes) and events. Tourism is also effected by natural disasters and catastrophes such as hurricanes, tsunamis, floods, avalanches and human created catastrophes such as nuclear disaster. The environment can be furthermore endangered by pollution and exploitation of the natural resources that also effect the safety and security element of the travel.

The following safety and security elements are classified as major safety threats in tourism by Pizam and Mansfeld /9/. Firstly, the major security element is the crime rate in all different types (theft, robbery, kidnapping, sexual violence, financial fraud, forgery, drugs, prostitution, corruption and bribery). The next element is violence and violation of public peace and order due to demonstrations and hooliganism. Even more disturbing is the outbreak of war and consequently the occurrence of illegal migration. Last but not the least contemporary tourism is highly affected by terrorist attacks.

Terrorist attacks are considered as violent activities largely against civilians. The aim of these attacks are to reach the political objectives of the terrorist group with threats and violence. Terrorism is a global phenomenon and no country is safe from it; it causes many fatal casualties and generates high media coverage. These are characteristics of terrorism that can be related to tourism, as Sönmez wrote /10/. Tourists and tourist sites are an especially desirable target for terrorist attacks since there is a mass of people at one place and the effect is hence bigger. These locations are for example restaurants and hotels, all types of mass transport and mass events venues, where people are queuing. 
Terrorists have much to gain by targeting tourists; targeting tourists helps them achieve their strategic objectives. These short- or long-term objectives may include using excitement and commotion at tourist centers as a cover for their activities, as a means of economic destabilization or in gaining much needed media attention and the opportunity for identity or destruction of national symbols. The mass media have a significant influence on tourists and their decision making process and they generate perceptions about the destination $/ \mathbf{1 1} /$.

The research "Safety and security and the choice of a tourist destination" which was conducted in Slovenia in 2010 /12/ showed that when choosing a destination, tourists initially consider the destination itself, thereafter issues about the price and finally about safety and security conditions. Only parents, traveling with children, put the safety and security factor first. But when regarding safety and security elements alone, the respondents described as most hazardous, war and armed conflict, followed by terrorism, street criminality, accommodation safety, political stability of the country, crime-levels in the country, travel safety and the potential risk for natural disasters.

The effects of safety and security violation on tourism are varied as stated in an article by Sönmez, Apostolopoulos \& Tarlow /13/. Firstly, the life and health of the tourist is endangered and with this kind of experience, the tourist usually terminates their stay at a destination. Other tourists may cancel their reservation or transfer to another destination. The negative media coverage diminishes the good image of the destination and the tourist demand decreases. Furthermore, the destination alone can be destroyed and not only tourism, but also other economic sectors may feel the recessionary effect.

Much research on the effects of safety and security violation on tourism have been conducted in previous years. Floyd, Gibson, Pennington-Gray \& Thapa /14/ wrote that the focus has been mainly on effects of terrorist attacks. They summarize the findings of Pizam and Fleischer who concluded, that if a serious terrorism attack was a onetime event, then terrorism impacts the destination only in a short term of 6 to 9 months, when tourist demand decreases. After this period the destination starts to recover. Much more fatal for a destination are continuous terrorism attacks, that leave long-term negative impacts on tourist demand, since the destination is marked as risky and dangerous and tourists will avoid it.

Fletcher and Morakabati /15/ suggested that when subjected to an event a country's tourism industry is likely to pass through three distinct phases. The first phase is in the immediate aftermath of the event when tourist arrivals and expenditures drop sharply or cease completely, depending upon the severity of the event. At this stage, the destination is reacting to the event, repairing damaged superstructure where applicable, reducing prices to increase attraction and attempting to restore stability and confidence. This is followed by the second phase where there is, hopefully, a sustained period of recovery. This second phase is not complete until the volume of tourist arrivals have achieved a level that is commensurate with where it would have been, at that later time, had there not been such an event. The third phase extends full recovery further because the destination has to recover the loss of receipts incurred as a result of the event and as a result of reducing prices in an attempt to restore demand. Of course, under some circumstances, where the threat of further attacks cannot be reduced, the destination may not recover the losses caused by the event. Nonetheless, experience to date suggests that with one-off events the destination does recover and it is only when there is continued unrest or repeated attacks that recovery does not materialize.

Figure 1 demonstrates the three phases of disruption of tourist arrivals after terrorism attack. The solid growth of the arrivals line reflects the long term tourism development of the destination. At time period ' $G$ ' a one-off event occurs, perhaps a terrorist attack that causes arrivals to drop sharply from ' $A$ ' down to level ' $\mathrm{B}$ ' after which the number of visitors 
starts to increase again until time period ' $\mathrm{H}$ ' when the number of visitors is back on the long term growth line. The loss in arrivals is the area ' $Y$ ' under the growth line. The dotted expenditure line follows a similar pattern to that exhibited by the arrivals line. At time point ' $G$ ' the event occurs and expenditure drops dramatically down to level ' $\mathrm{D}$ '. It is likely that expenditures will fall more rapidly and take longer to recover than arrivals as the des- tinations drops prices in order to attract visitors back. Full recovery of expenditures is not restored until time point ' $\mathrm{I}$ ', which is likely to be some period after ' $\mathrm{H}$ ', as the destination has to restore not only the lost receipts from the drop in tourism activity but also the loss in receipts by having to discount the tourism products. The total loss in receipts is shown by the area under the dotted curve ' $\mathrm{N}$ '.

Figure 1: The disruption of tourist arrivals and receipts following a terrorist attack or political unrest

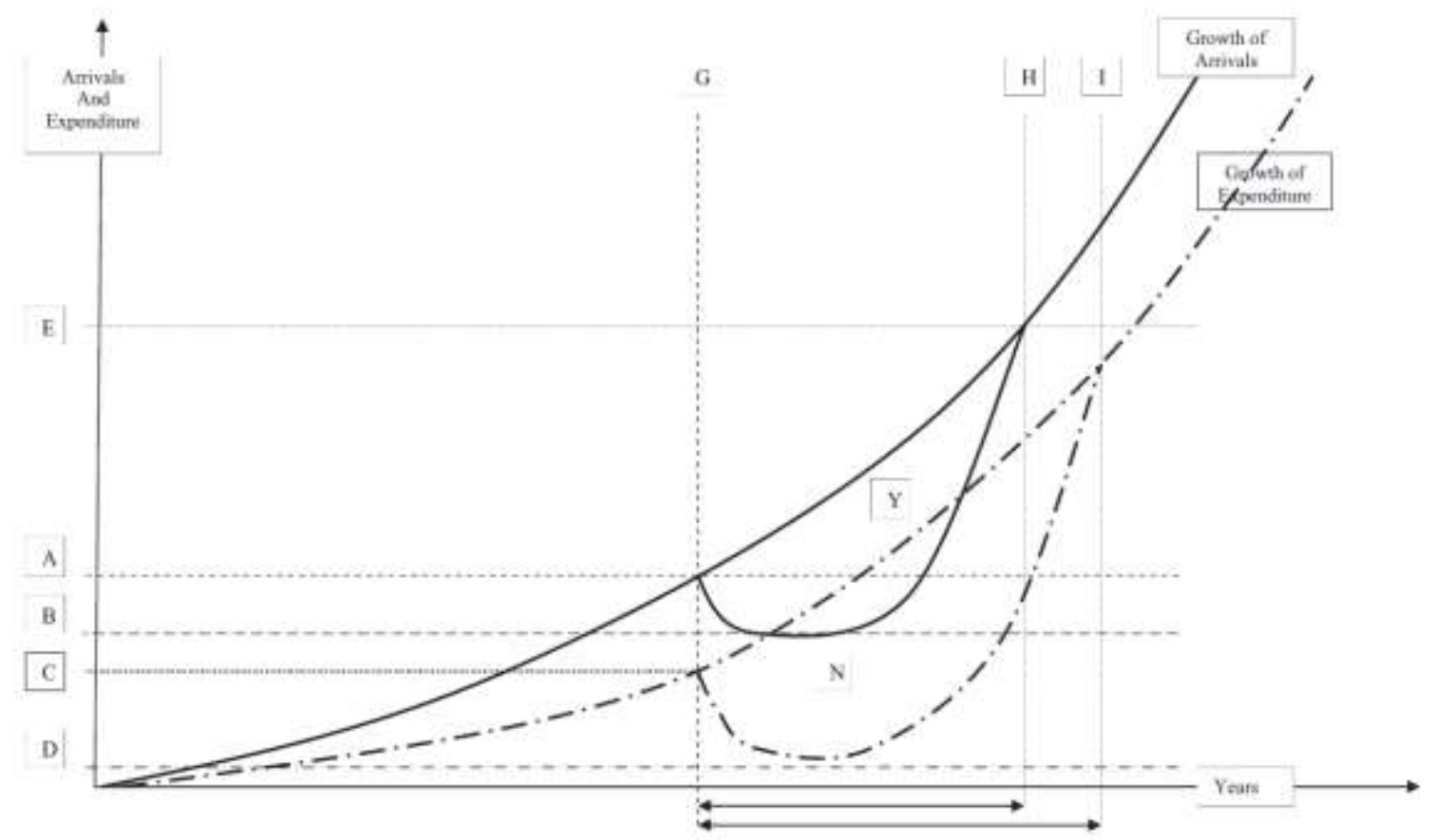

Source: Fletcher and Morakabati, 2008

In order to start the recovery phase as soon as possible, the destination should undertake various steps. Firstly, it should take care, that the safety and security conditions are properly provided for - intensified traffic control, security checks, no more queuing, better health standards, reachable first aid, high environment standards etc. should be ensured. Secondly, the positive image of the destination should be restored by highlighting competitive advantages of the destination, selling special offers and nurturing good relationships with properly selected target market and media. Furthermore the destination should increase the cooperation with foreign governments and tourism representatives. The information about the improved safety and security conditions at the destination must be realistic and the tourism representatives should verify that at the site while attending study tours at the destination. And lastly, the destination should offer some new tourism products that attract the existing and new guests from abroad and domestically. These suggestions are also considered by many authors for example Sönmez, Apostolopoulos \& Tarlow. 
DESIGNING TOURIST PRODUCTS IN THE LIGHT OF SAFETY AND SECURITY

Another challenge with safety and security is to manage questions by travel agencies, given that travel agents should consider gathering and providing the accurate information about safety and security conditions at the destination. If they decide to continue selling the destination, they should enhance the promotion, make it more interesting, lower the prices or target new potential customers. Travel agencies can also adjust the products they are selling. They can choose to accommodate their guests in a more secure quarter or in a safer hotel, they can decide to travel with other means of transport or to shorten the time of staying at one destination. The ultimate measure is to abandon the offer of a risky destination and to redirect tourists to another destination.

The research "New Zealand Travel Agent Practice in the Provision of Advice for travel to Risky Destinations." /16/, which was conducted amongst New Zealand travel agents, showed many interesting findings about the travel agent's inclination towards safety and security. The research indicated that travel agents provide safety information about destinations and one third stated that their travel agencies had specified directions about providing information that they have to follow. Travel agents primary sources on safety and security dimension for the chosen destinations are: mass media, social media, personal experience, foreign governments and the embassies of their own countries.

Furthermore, the research question was whether travel agents would continue or discontinue to sell a risky destination. Findings show, that more than a half of travel agents would continue with the selling regardless of their personal experience with the destination, their attitude towards risk, use of information sources etc. The others would discontinue with the selling in order to ensure customer safety or because of lack of the demand. The author's interpretation of these results was that the travel agent will not personally visit the risky destination, hence there is no personal risk and the destination can be sold. Other motivation to sell risky destination is the ethical obligation towards customer to fulfil their every demand - as well known proverb says: "The customer is king".

Travel agents' basic knowledge of customer relations, destinations, safety and security issues should be gained not only through personal experience but also in a process of formal education. Education in tourism is an important part of ensuring excellency in tourism. The beginning of hospitality higher education (HE) dates back to 1893, when a dedicated hotel college, Ecole Hoteliere de Lausanne, was established in Switzerland. As Amoah and Baum /17/ wrote, tourism education programmes have emerged in response to different needs for human resource development in a challenging environment as stated below:

1. Keeping the industry abreast of the latest technology and trends.

2. The availability of qualified replacement staff at all times.

3. Raising the image of careers in tourism.

4. Staffing new and growing tourist industries.

5. Employment regulation.

6. Reduction of foreign labour.

7. Responding to increasingly demanding service and communications requirements of customers.

Furthermore, it is important to recognise the importance of long-term planning in sustainable tourism development. This also requires an education with greater insight of trends and events that will shape the tourism of tomorrow. Some countries have recognized this potential and established state agencies responsible for the recruitment, education and training of personnel at all levels for the hotel, catering and tourism industry (e.g. Ireland, Canada). These agencies help to formulate a tourism education policy that answers the challenges of contemporary tourism and operate under the authority of a board representative of employers, trade unions, educational institutions, governmental and public agencies. 
All listed tourism organizations will anticipate that future tourism graduates will have various knowledge and skills to perform their job. Graduates will require to be acquainted with the psychological, social and cultural environment of the tourist and pursue their needs, motives, wishes and anticipations. Whilst creating the overall tourism product, future tourism employees should also consider the multitude of tourism components (e.g. transportation, accommodation, food and leisure) and participants (e.g. carriers, hotel and restaurant owners, traders, landowners, oversight and coordination bodies, local councils) in order to present a coherent and integrated product that produces a feel-good sensation, comfort, positive feelings and consequently a constructive emotion, which is simply energy in motion /18/. An important part of the tourism product is its promise of a safe and secure environment, in which the product is placed in. Through the process of tourism education, students should become aware of its importance and consider safety and security as an equal component to others.

Designing a tourism product is a complex task requiring in addition to good knowledge and skills the ability to develop a destination tourist product attitude. The basic idea of this experimental research was to examine whether the media display of a terrorist attack affects the attitude of students towards the tourist destination.

\section{RESEARCH EXPERIMENT - METHOD}

The study was designed as an experimental research in two groups (pre-test and post-test models). Students were invited to a seminar on designing a new tourism product, with the lectures given by professors from the Faculty of Tourism Univesity of Maribor, Slovenia and a professor at the University of Libertas, Croatia. At the beginning of the seminar students were told that during the seminar a research study would be conducted and that they would be invited to answer questions structured in a number of questionnaires. All of the students agreed to voluntarily participate in the study. Before the start of the lecture, stu- dents were asked to answer questions in the following questionnaires:

1. General questionnaire with basic demographic data;

2. Questionnaire on Bogardus Social Distance;

3. Questionnaire on assessment of tourist destinations of Paris, Brussels, Istanbul and Ankara;

4. Nonverbal semantic differential where as the leading terms were the names of the cities of Paris, Brussels, Istanbul and Ankara.

Both groups of participants at the start of lectures were shown propaganda films on tourism aspects of Paris, Brussels, Ankara and Istanbul.

The students listened to three lessons:

1. Elements of tourist destinations;

2. Methods of designing tourist product and

3. Safety as part of a tourist destination management.

Students included in the research experiment, initially learned about destination planning regarding safety and security - how unsafe and insecure environments have an effect on destinations; which target groups are most easily affected by safety and security issues and how can a destination build a safe and secure environment as well as recovering its reputation. In the course of the experiment, all students had participated in a lecture about safety and security in the process of destination planning. They were introduced to the theory of safety and security - from the Maslow theory of needs, human rights to safety and security in tourism. The lecture presented elements of safety and security in tourism (e.g. health issues, traffic accidents, crime, natural disasters, terrorism) and an historical overview of the perceived importance of safety over the last century. The last topic of the lecture was a travel agent's perspective on safety and security of destination and their role in promoting destinations with potential safety and security issues.

In the first two lessons, students were listening together; but then before the lessons on security aspects of designing new tourism products, the students were divided into two groups. 
Groups were working in separate areas and the premises were secured so that students were not able to communicate with each other. The experimental group was shown films from different media about the terrorist attacks in the cities. The control group only listened to the lesson about safety and security without watching the films. After completion of the course and after the presentation of short films, students were again asked to complete:

1. A questionnaire on assessment of tourist destinations of Paris, Brussels, Istanbul and Ankara;

2. A nonverbal semantic differential where the leading terms were the names of the cities of Paris, Brussels Istanbul and Ankara.

\section{INSTRUMENTS}

The study applied several instruments. Some of the instruments are well known and often used, some are rarely used, in this case an instrument was made by experts of the Faculty of Tourism just for the purpose of this research. First is a questionnaire, which has gathered some basic demographic data on age, level of studies and personal and family integration of students with tourism and hospitality industry. The second instrument was Bogardus scale of social distance. As usual, respondents on a scale from 1 to 3 had to evaluate to what extent he/she was close to a member of another nation in the role of a) friend; b) the spouse; c) co-worker; d) a citizen of Slovenia; e) politicians in Slovenia; f) the president of Slovenia g) neighbours; h) someone who they are in a relationship with. In the questionnaire were offered members of 10 European countries and one national minority which appear in most European countries, Roma.

The instrument was used only at the start of the study. The idea was to study what are the attitudes of Slovenian students towards some of the nations in Europe. The next one was a questionnaire on the assessment of tourist destinations. The questionnaire was designed as an inventory of the necessary characteristics to be included in a tourist destination in order to successfully prepare a new tourist product.
Assistant Professor Marko Koščak prepared the instrument for this research. The instrument contains 7 common dimensions of tourist destinations, such as service facilities, activities at the destination, natural resources, aesthetic value destinations, environmental quality, destination marketing and political instability. These areas include from 2 to 5 sentence of the description of each of the dimensions. The scale for the evaluation of each claim is in the range of 1 to 3 . For each of the four destinations to which we have decided to include in this study, respondents had to answer the entire questionnaire. The instrument is used at the beginning and at the end of the study. The last instrument has been a graphically semantic differential of Bentler and Lavoie.

Non-verbal semantic differential is an instrument which is rarely used in research practice, and in tourism, its use is almost unknown. The semantic differential is an instrument for measuring the connotative dimensions of the meaning of terms. It is based on the assumption that some conflicting notions contain varying degrees of positive or negative emotional significance. The respondent should differentiate between the meanings of differing terms and identify one specific meaning; hence the name of the "semantic differential". In this study, different thumbnail drawings that replace words are used instead of words or terms, while they are universal and useful in different cultures and with people who are illiterate. Another important advantage of the non-verbal semantic differential, is smaller level of social conformity in respondents or, it could be postulated, that respondents are having more difficulty in controlling their own social conformism. The instrument is testing 5 connotative areas, which are: Orderliness, Density, Activity, Potency and Evaluation. Bentler and Lavoie /19/ introduced two connotative areas in addition to Osgood's original instrument - orderliness and density.

\section{THE SAMPLE}

The sample was convenient. Altogether 63 students participated who were in class that day in the afternoon; they were invited to a special seminar on methods for the design of a 
new tourism product. There were 20 men and 43 women, which corresponds to the gender distribution of students of the Faculty of Tourism. According to the degree of the study, students were distributed as follows in Table 1.

Table 1: Students according to the degree

Professional degree 37

University degree 14

Master degree

Total

This distribution corresponds to the distribution of students at certain stages of the study. For students aged 19 to 44 years, the average age was 22.49 years. However, most students are in the younger age groups, the mode is 20 years, and in this group is one-third of students. As can be seen from Table 2, the majority of the students are from rural areas. Only one-fifth of students are from major Slovenian cities.

Table 2: Type of settlement from which the student comes

\begin{tabular}{|l|l|l|}
\hline & Number & $\%$ \\
\hline In the countryside & 34 & 53,97 \\
\hline A small town & 17 & 26,98 \\
\hline City (Ljubljana or Maribor) & 12 & 19,05 \\
\hline Total & 63 & 100,00 \\
\hline
\end{tabular}

Table 3: How are tourist destination rated?

Brussels - total assessment
$\begin{aligned} & \text { Mean } \\ & \text { Istanbul- total assessment }\end{aligned}$
Paris- total assessment
Ankara- total assessment
As can be seen from the Table 3, in the opinion
of the students who participated in the exper-
iment, the highest score was given to the des-

We asked the students whether any of their family members are engaged in tourism activities or whether they own some tourist facility. Only 7 students or $11.11 \%$ answered that some of the family members are engaged in tourism business, and the remaining $88.88 \%$ responded that no one in the family is engaged in any form of tourist activity. When it comes to the hospitality industry, then twice more students respond that one of the family members owns a catering facility (14 or $22.22 \%$ ), while 49 of the sample $(77.68 \%)$ responded that no one in the family owned a hospitality business. Owning a small inn has a long tradition in rural areas of Slovenia.

A majority of the students, before studying at the Faculty of Tourism, completed studies at a professional school (40 or $64.52 \%$ ), and only about one-fifth of them (22 or $35.48 \%$ ) finished grammar schools, which qualify for university education.

After the general part of the lecture, the students were divided into two groups at random distribution.

\section{RESULTS AND DISCUSSION}

The students were invited to attend a seminar on the topic of designing a new tourism product. This product would be a tourist trip to one of the four famous destinations: Paris, Brussels, Ankara and Istanbul. Students were asked to mark on the basis of a questionnaire assessment of that destination, before they were held lectures on methods of assessment destination. Students evaluated destinations in the following manner.
Std. Deviation

5,21

5,46

4,28

6,05

tination Brussels and the lowest to Ankara. According to the values of skewness and kurtosis, the variables do not deviate significantly 
from the normal distribution, so it is possible to implement other statistical procedures in the field of parametric statistics. The order of the assessment of the individual destination, points to the professionalism of the students who participated in the experiment. Although according to the Bogardus scale of social distance, French assessed far more than the Turks, Istanbul was rated as a tourist destination rather than Paris. Participants in the experiment were asked to rate members of 11 European nations. In the first place were rated Germans, and in the last reasonable degree, Roma. Turks were rated on the penultimate, 10 th place. The French are in fourth place, so far above the Turks, but the destination of Istanbul was still judged better than Paris.

Table 4: Evaluation of destination before and after the film

Paris before film

Mean

Std. Deviation

Paris after film

Mean

Std. Deviation

Brussels before film

Mean

Std. Deviation

Brussels after film

Mean

Std. Deviation

Ankara before film

Mean

Std. Deviation

Ankara after film

Mean

Std. Deviation

Istanbul before film

Mean

Std. Deviation

Istanbul after film

Mean

Std. Deviation
Students of the first (control) group did not see movies of the terrorist attacks, and the second - (experimental group) - saw short films of the terrorist attacks. As can be seen from the Table 4 , in the evaluation of destination there did not appear a statistically significant difference, except when it came to the destination of Brussels. The group of students who had the opportunity to see a film about a terrorist attack evaluated the destination of Brussels statistically significantly lower than before the film. We assume that this happened because the destination Brussels was at the beginning of the program and the students judged it as the best in almost all seven dimensions.

48,62

$\begin{array}{ll}4,28 & \text { No statistical } \\ 47,49 & \text { significance }\end{array}$

6,93

50,09

5,21 significant

46,56 difference

$8,00 \quad \mathrm{p}=0.037$

47,56

6,05 No statistical

45,65 significance

7,95

48,66

$5,46 \quad$ No statistical

45,68

significance

6,84
The situation is however quite different when applied to non-verbal semantic differential (Table 5). Almost all five scales appear to have statistically significant differences in the experience of the participants of the experiment. Exceptions are only in regard to scale evaluation when it comes to Brussels, where the im- pact of images of the terrorist attack did not lead to changes in the evaluation. Also, there were no statistically significant differences when it related to the scales Activity and Orderliness when evaluating Istanbul, and on a scale in regard to the Orderliness of Ankara. 
Table 5: Results on graphic semantic differential test

\begin{tabular}{|c|c|c|c|c|c|}
\hline & $\begin{array}{l}\text { Pretest/ } \\
\text { Posttest }\end{array}$ & Mean & $\begin{array}{l}\text { Std. } \\
\text { tion }\end{array}$ & Devia- & Sig. \\
\hline \multirow{2}{*}{ Evaluation-Brussels } & Pretest & 3,26 & 5,07 & & \multirow{2}{*}{ 111 } \\
\hline & Posttest & 1,32 & 6,20 & & \\
\hline \multirow{2}{*}{ Potency-Brussels } & Pretest & 2,48 & 4,15 & & \multirow{2}{*}{,029 } \\
\hline & Posttest & 16 & 5,81 & & \\
\hline \multirow{2}{*}{ Activity-Brussels } & Pretest & 2,98 & 4,38 & & \multirow{2}{*}{,007 } \\
\hline & Posttest & ,23 & 4,76 & & \\
\hline \multirow{2}{*}{ Density-Brussels } & Pretest & 5,89 & 4,02 & & \multirow{2}{*}{,014 } \\
\hline & Posttest & 3,39 & 5,44 & & \\
\hline \multirow{2}{*}{ Orderliness-Brussels } & Pretest & 3,76 & 4,78 & & \multirow{2}{*}{,001 } \\
\hline & Posttest &,- 16 & 6,00 & & \\
\hline \multirow{2}{*}{ Evaluation-Istanbul } & Pretest & 3,45 & 3,94 & & \multirow{2}{*}{,000 } \\
\hline & Posttest &,- 71 & 6,45 & & \\
\hline \multirow{2}{*}{ Potency-Istanbul } & Pretest & 1,58 & 4,61 & & \multirow{2}{*}{,004 } \\
\hline & Posttest & $-1,65$ & 5,54 & & \\
\hline \multirow{2}{*}{ Activity-Istanbul } & Pretest & 1,32 & 4,12 & & \multirow{2}{*}{ 103 } \\
\hline & Posttest &,- 26 & 4,82 & & \\
\hline \multirow{2}{*}{ Density -Istanbul } & Pretest & 5,08 & 4,05 & & \multirow{2}{*}{,004 } \\
\hline & Posttest & 1,74 & 6,94 & & \\
\hline \multirow{2}{*}{ Orderliness-Istanbul } & Pretest & $-1,74$ & 5,028 & & \multirow{2}{*}{,346 } \\
\hline & Posttest & $-2,87$ & 6,13 & & \\
\hline \multirow{2}{*}{ Evaluation-Paris } & Pretest & 5,23 & 4,71 & & \multirow{2}{*}{,001 } \\
\hline & Posttest & 839 & 7,23 & & \\
\hline \multirow{2}{*}{ Potency-Paris } & Pretest & 3,21 & 4,32 & & \multirow{2}{*}{,007 } \\
\hline & Posttest & ,00 & 6,75 & & \\
\hline \multirow{2}{*}{ Activity-Paris } & Pretest & 2,80 & 4,79 & & \multirow{2}{*}{,036 } \\
\hline & Posttest &, 55 & 4,85 & & \\
\hline \multirow{2}{*}{ Density-Paris } & Pretest & 6,50 & 4,36 & & \multirow{2}{*}{,000 } \\
\hline & Posttest & 1,71 & 6,71 & & \\
\hline \multirow{2}{*}{ Orderliness-Paris } & Pretest & 3,77 & 4,42 & & \multirow{2}{*}{,000 } \\
\hline & Posttest & $-1,52$ & 6,70 & & \\
\hline & Pretest & 1,74 & 4,86 & & \\
\hline 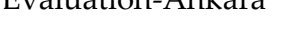 & Posttest & $-1,60$ & 7,13 & & \\
\hline
\end{tabular}




\begin{tabular}{lllll}
\hline \hline \multirow{2}{*}{ Potency-Ankara } & Pretest & 1,13 & 5,04 &, 044 \\
& Posttest & $-1,32$ & 6,20 & \\
Activity-Ankara & Pretest & 1,52 & 4,55 &, 007 \\
& Posttest & $-1,17$ & 4,05 &, 011 \\
Density-Ankara & Pretest & 4,29 & 4,92 &, 123 \\
& Posttest & 1,00 & 7,09 & \\
Orderliness-Ankara & Pretest & $-2,13$ & 6,62 & \\
& Posttest & $-4,32$ & 5,95 &
\end{tabular}

It is obvious that the emotional component that is included in the non-verbal test, is far more difficult to control. This resulted in statistically significant differences on most scales of semantic differential. One possible explanation, is the fact that in the graphic semantic differential pronounced visual character of the test. On the other side is a variable that created the difference between testing also of visual character, namely, a short film story of the terrorist attacks in cities that have provided us with a starting point in the analysis. Visual images denote and imply sensory processing of the facilities, which are offered to participants in the experiment. It is therefore likely that the meaning is the same or approximately the same for all participants. This may not be the case when it comes to verbal stimuli, as they were in the questionnaire, which evaluated destinations. This reminds us about the need for the creation of the tourism product to use very different sources (here verbal and visual), because the use of only one type of sources may lead to bias, which probably happened in this experimental situation.

\section{CONCLUSION}

Safety and security issues define our modern world, and specifically the field of tourism. In this study, we wished to examine whether the media display of a terrorist attack affects the designing of the tourism product. As previous research indicates, a personal attitude towards a destination plays an important role in this process. Hence, we examined the attitude of tourism students towards tourist destination.
We used an experiment; a method that it is not often used in tourism studies and also which made a unique questionnaire on assessment of tourist destinations for the research, which may be also used in other studies about tourism destinations.

As research results indicate, four tourist destinations Paris, Brussels, Ankara and Istanbul were at the beginning of the experiment all evaluated with an average assessment and no major deviation among them. After the experiment the results of the second questionnaire on the assessment of tourist destinations, did not show statistically significant difference between destinations, excepting in the situation of the destination of Brussels, which was lower than before the film. The situation is different when applied to non-verbal semantic differential where almost all five scales show statistically significant difference in the experience of the participants of the experiment. The difference was noticeable in this questionnaire with visual images since we have used visual media - films, to address safety and security regarding studied destinations. With this result we can conclude, that visual media affects our attitude towards destinations. The experiment also proved, that tourist workers who design tourist products are human beings who are subject to both practical thinking and to emotional responses. When the experimental and the control groups answered the standard questionnaires, there was no difference between groups. They both perceived the destinations through a practical, business perspective, where the product must be offered to purchase. But when the emotions were being 
addressed through semantic differential, the differences were noticeable since the experiment participants answered on the basis of their own feelings towards the destinations. They felt unsafe when watching visual media of terrorist attacks and therefore they perceived the destination as less safe.

This experiment is a valuable foundation for further research as it would be interesting to conduct a study among travel agents themselves. Also the use of nonverbal semantic differential has a great potential in research of tourist attitude towards destination, tourist products and other tourism issues. The visual images used in the questionnaire are universal and meaningful to people from different cultures and with people who are illiterate. Additionally, the meaning is the same or approximately the same for all participants and it more realistically presents the real attitude with smaller level of social conformity.

\section{Notes}

/1/ Pizam, A., Mansfeld, Y. (2006). Toward a theory of tourism security. Tourism, security and safety: From theory to practice, 1-28.

/2/ Kozak, M., Crotts, J. C., Law, R. (2007). The impact of the perception of risk on international travellers. International Journal of Tourism Research, 9(4), 233-242.

/3/ Kurež, B., Prevolšek, B. (2015). Influence of security threats on tourism destination development. TIMS. Acta, 9(2), 159-168.

/4/ Kozak, M. (2002). Comparative analysis of tourist motivations by nationality and destinations. Tourism management, 23(3), 221-232.

/5/ Royo-Vela, M. (2009). Rural-cultural excursion conceptualization: A local tourism marketing management model based on tourist destination image measurement. Tourism Management, 30(3), 419-428.

/6/ Lexow, M., Edelheim, J. (2004). Effects of negative media events on tourist's decisions. School of Tourism and Hospitality Management Papers, 13.

/7/ Ritchie, B. J. Crouch, G. I. (2005). The Competitive Destination: A Sustainable Tourism Perspective. Wallingford: CABI Publishing.

/8/ Kim, S. S., Morrsion, A. M. (2005). Change of images of South Korea among foreign tourists after the 2002 FIFA World Cup. Tourism Management, 26(2), 233-247.

19/ Pizam, A., Mansfeld, Y. (2006). Toward a theory of tourism security. Tourism, security and safety: From theory to practice, 1-28.

/10/ Sönmez, S. F. (1998). Tourism, terrorism, and political instability. Annals of Tourism Research, 25(2), 416-456.

/11/ Lexow, M., Edelheim, J. (2004). Effects of negative media events on tourist's decisions. School of Tourism and Hospitality Management Papers, 13.

/12/ Ciperle, M. Dobovšek, B. (2011). Varnost in izbira turistične destinacije. Edited by Mekinc, J. \& Dobovšek, B., Varnost v turizmu (pg. 63-89). Koper: Univerzitetna založba Annales.

/13/ Sönmez, S. F., Apostolopoulos, Y., Tarlow, P. (1999). Tourism in crisis: Managing the effects of terrorism. Journal of travel research, 38(1), 1318.

/14/ Floyd, M. F., Gibson, H., Pennington-Gray, L., Thapa, B. (2004). The effect of risk perceptions on intentions to travel in the aftermath of September 11, 2001. Journal of Travel \& Tourism Marketing, 15(2-3), 19-38.

/15/ Fletcher, J., Morakabati, Y. (2008). Tourism activity, terrorism and political instability within the commonwealth: The cases of Fiji and Kenya. International Journal of Tourism Research, 10(6), 537-556.

/16/ Lovelock, B. (2003). New Zealand Travel Agent Practice in the Provision of Advice for travel to Risky Destinations. Edited by Hall, C. M., Timothy, D. J. \& Duval, D. T. Safety and Security in Tourism: Relationships, Management, and Marketing (Journal of Travel \& Tourism Marketing), Vol. 15, No. 4. Pg. 259-279.

/17/ Amoah, V. A., Baum, T. (1997). Tourism education: policy versus practice. International Journal of Contemporary Hospitality Management, 9(1), 512.

/18/ Doncean, M. (2014). The role of emotions in the process of knowledge of Tourism products. Agronomy Series of Scientific Research, 57(1), 259262.

/19/ Bentler, P. M., LA VOIE, A. L. (1972). A nonverbal semantic differential. Journal of Memory and Language, 11(4), 491-496.

\section{Literature}

1. Baum, T. (2015). Human resources in tourism: Still waiting for change?-A 2015 reprise. Tourism Management, 50, 204-212.

2. Dale, C., Robinson, N. (2001). The theming of tourism education: A three-domain approach. 
International Journal of Contemporary Hospitality Management, 13(1), 30-35.

3. Daniel, A. D., Costa, R. A., Pita, M., Costa, C. (2017). Tourism Education: What about entrepreneurial skills?. Journal of Hospitality and Tourism Management, 30, 65-72.

4. Hsu, C. H., Xiao, H., Chen, N. (2017). Hospitality and tourism education research from 2005 to 2014: "Is the past a prologue to the future?". International Journal of Contemporary Hospitality Management, 29(1), 141-160.

5. Hu, W., Wall, G. (2005). Environmental management, environmental image and the competitive tourist attraction. Journal of sustainable tourism, 13(6), 617-635.

6. Inui, Y., Wheeler, D., Lankford, S. (2006). Rethinking tourism education: What should schools teach. Journal of Hospitality, Leisure, Sport and Tourism Education, 5(2), 25-35.

7. Kapuscinski, G. (2014). The Effects of news media on leisure tourists' perception of risk and willingness to travel, with specific reference to events of ter- rorism and political instability (Doctoral dissertation, Bournemouth University).

8. Krešić, D., Prebežac, D. (2011). Index of destination attractiveness as a tool for destination attractiveness assessment. Turizam: međunarodni znanstveno-stručni časopis, 59(4), 497-517.

9. Kurež, B., Mekinc, J., Anžic, A. (2009). Človekove pravice $\mathrm{v}$ luči novih groženj varnosti. Teorija in praksa, 46(5), 170-185.

10. Mansfeld, Y., Pizam, A. (Eds.). (2006). Tourism, security and safety. Routledge.

11. Maslow, A. H. (1943). A theory of human motivation. Psychological review, 50(4), 370-396.

12. Ovsenik, R., Bukovec, B., Ovsenik, M. (2015). Izobraževanje za turizem v Sloveniji. Novo mesto: Fakulteta za organizacijske študije.

13. Smith, S. L. (1987). Regional analysis of tourism resources. Annals of tourism research, 14(2), 254273.

14. Telisman-Kosuta, N. (1989). Tourist destination image. Tourist destination image, 557-561. 